\title{
Evaluation of the impacts of land-based contaminants on the benthic faunas of Jakarta Bay, Indonesia
}

\author{
John G. REES ${ }^{a^{*}}$, Deddy SETIAPERMANA ${ }^{b}$, Vincent A. SHARP ${ }^{\text {, }}$, Jason M. WEEKS ${ }^{d}$, T. Martin WILLIAMS ${ }^{\text {a }}$ \\ ${ }^{a}$ British Geological Survey, Keyworth, Nottingham NG12 5GG, UK \\ ${ }^{\mathrm{b}}$ Indonesian Institute of Sciences, Research and Development Centre for Oceanology, Ancol, Jakarta, Indonesia \\ ${ }^{\mathrm{c}}$ Centre for Tropical Coastal Management Studies, Department of Marine Sciences and Coastal management, \\ University of Newcastle, Newcastle-Upon-Tyne, UK \\ ${ }^{\mathrm{d}}$ Institute of Terrestrial Ecology, Monks Wood, Abbots Ripton, Huntingdon, UK
}

Revised 25 May 1999; accepted 28 May 1999

\begin{abstract}
To evaluate the impact of land-based contaminants on benthic faunas, as part of the Land-Ocean Contamination Study (LOCS), a study transect was established in Jakarta Bay, Indonesia during the 1996 southeasterly monsoon. The transect extended $72 \mathrm{~km}$ between the city's main port, Tanjung Priok, and the Pilau Seribu Island chain in the Java Sea. The dissolved concentrations of $\mathrm{Pb}, \mathrm{Cu}, \mathrm{Zn}, \mathrm{Cr}$ and $\mathrm{Ni}$ in seawater, in suspended particulate matter ( $\mathrm{SPM}$ ) and surficial sea bed sediments were measured along the transect at nine sites. In addition, metal concentrations were measured in tissues of the corals Goniopora lobata and Lobophyllia hemprichii at five sites, and of the green mussel, Perna viridis at six sites. An assessment of the impact of contaminants on the faunas was made using a biomarker approach, employing coral community analysis and lysosomal stability with Perna viridis. The results of the study showed two main trends. The distributions of metals dissolved in seawater, in SPM, and in the coral and mussel tissues were similar, and failed to show a consistent graded response from inshore to offshore sites. This suggests that the concentration of metals in waters is the primary route for metal uptake by the coral and mussel tissues. By way of contrast, a clear offshore increase in coral generic diversity, coral cover, coral colony numbers and neutral-red retention time (lysosomal stability) was observed, suggesting increasing nearshore stress. Whilst the coral community stucture may reflect the seasonally-averaged metal distributions in the bay (shown by the metal content of sea bed sediments which increase shorewards), it is more likely that the coral community structure and lysosomal biomarker are responding principally to other nearshore stresses, such as sediment and nutrient loading of water (sewage) or, more likely, organic contaminants such as oils and other hydrocarbons. (C) 1999 Ifremer / CNRS / IRD / Éditions scientifiques et médicales Elsevier SAS
\end{abstract}

\section{Jakarta / contamination / biomarker / coral-community}

Résumé - Évaluation de l'impact de contaminants terrestres sur la faune benthique du golfe de Djakarta, Indonésie. Dans le cadre du programme Contamination Continent-Océan (LOCS, Land-Ocean Contamination Study), l'impact des contaminants terrestres sur la faune benthique du golfe de Djakarta (Indonésie) a été évalué en 1996, pendant la mousson du sud-est, sur une radiale de $72 \mathrm{~km}$ entre le port principal Tanjung Priok et la chaîne insulaire Pulau Seribu, dans la mer de Java. Les concentrations de $\mathrm{Pb}, \mathrm{Cu}, \mathrm{Zn}, \mathrm{Cr}$ et $\mathrm{Ni}$ dissous ont été mesurées : 1) dans l'eau de mer, dans les particules en suspension et dans les sédiments superficiels ( 9 stations) ; 2) dans les tissus des coraux Goniopora lobata et Lobophyllia hemprichii (5 stations) ; 3) dans les tissus de la moule verte Perna viridis (6 stations). L'impact des contaminants sur la faune a été évalué à l'aide d'un marqueur biologique, par analyse de la communauté corallienne et stabilité lysosomiale avec Perna viridis. Deux tendances principales ressortent de cette étude. Les répartitions des métaux dissous dạs l'eau de mer, dans les

* Correspondence and reprints: j.rees@ ogs.ac.uk 
particules en suspension et dans les tissus des coraux et des moules sont similaires, sans variation entre la côte et le large, ce qui suggère que l'eau est la voie d'absorption des métaux par les tissus des coraux et des moules. À l'inverse, une nette augmentation est observée au large dans la diversité des genres coralliens, dans la couverture corallienne, dans le nombre des colonies de coraux et dans le temps de rétention du rouge-neutre (stabilité lysosomiale), ce qui indique un accroissement des contraintes vers la côte. Bien que la structure de la communauté corallienne représente la moyenne saisonnière de la répartition des métaux dans le golfe (illustrée par la teneur en métal des sédiments, croissante vers le rivage), il est probable que la structure de la communauté corallienne et le biomarqueur lysosomial répondent surtout à d'autres contraintes côtières, comme la charge en sédiments et en nutriments (égouts) ou, plus probablement, en contaminants organiques tels que le pétrole et les autres hydrocarbures. (C) 1999 Ifremer / CNRS / IRD / Éditions scientifiques et médicales Elsevier SAS

\section{Djakarta / contamination / biomarqueur / communauté corallienne}

\section{INTRODUCTION}

Shallow marine environments in tropical regions support a wide range of habitats that are not only environmentally sensitive, but support economically indispensable fisheries and tourist sectors in many developing countries. In many areas the habitats are becoming degraded, if not destroyed, as a result of high sedimentation rates, nutrient loading and chemical contamination, as well as physical destruction associated with human harvesting of resources. Coral reefs, in particular, are important in terms of the continued productivity and diversity of the tropical coastal waters they sustain. In these, reef-building corals form part of the initial trophic level with their endosymbiotic algae (zooxanthellae), and also provide the majority of habitat structures for associated organisms [37]. The reefs are physically important due to their role in the reduction of wave energy, particularly from typhoons, in protecting coasts from erosion and providing a supply of carbonate material for the development and growth of islands and coastal margins.

In recognition of the value of these habitats, and the fact that future social and economic development in tropical regions will inevitably involve the accelerated urbanisation of coastal margins, the UK Department for International Development (formerly the Overseas Development Administration) funded the Land-Ocean Contamination Study (LOCS). The central objective of this programme was the provision of improved techniques for contaminant monitoring, impact amelioration and integrated coastal-zone management, appropriate for use in tropical countries at varying levels of technological development. The programme included case studies, focusing on the reef-fringed coastal margins of East Africa [59], lagoons of the Brazilian Atlantic coast, and the more industrialised setting of Jakarta Bay, Indonesia. The aim of the latter phase, part of which is the subject of this paper, was to construct a detailed picture of the sources, transport pathways and ecological impacts of contaminants entering the waters of Jakarta Bay. Geochemists and sedimentologists from the British Geological Survey worked on the measurement of heavy metal and organic pollutant concentrations in water, sediment and suspended particulate matter, and biologists from the UK Institute of Terrestrial Ecology and the University of Newcastle, Centre for Tropical Coastal management Studies focused on the impacts of pollution on the biota, including the green mussel, Perna viridis (which is widely distributed in the Indo-Pacific and is a significant dietary item in parts of $\Lambda$ sia), and coral communities. All work was done in conjunction with staff of the Indonesian Institute of Sciences (LIPI), Research and Development Centre for Oceanology.

This paper summarises aspects of the LOCS programme which addressed the problem of evaluating the impacts of contamination on the benthos of Jakarta Bay. It focuses on heavy metal $(\mathrm{Pb}, \mathrm{Cu}, \mathrm{Zn}, \mathrm{Cr}$ and $\mathrm{Ni})$ distributions in water and sediments along a transect extending from the main port of Jakarta towards the Java Sea. In particular, it concentrates upon the impacts of the contaminants on two animal groups, coral communities and mussels, to facilitate the use of biomarkers for use in contaminant monitoring programmes. Full results of the programme, including details of organic contamination, and the distributions of metals over the area of the bay, are presented in a 3 -volume report series $[40,58,60]$.

\section{PROBLEMS IN EVALUATING IMPACTS OF CONTAMINATION ON THE BENTHOS}

In comprehensive contaminant monitoring programmes it is important, not only to understand the sources, transport paths and fates of contaminants, but to appreciate the 
impact of these on the benthos. The uptake of contaminants by animals (and associated stress suffered by exposure to them) in turn governs the health, and future viability, of biological habitats, and the passage of contaminants into food chains.

It is possible to estimate the impacts of contamination on fauna directly, by measurement of contaminants in animals, or by directly monitoring the reponse of the animals to stress caused by the contaminant. The measurement of heavy metal burdens in corals and mussels has been undertaken many times before $[8,13$, 18-20, 28]. However, as the contaminant content of animals cannot be taken as a direct measure of the stress suffered, and because costs of analytical programmes are often beyond the budget of developing countries, direct, cheaper methods of monitoring contamination impact are favoured. One approach is to use biomarkers to assess impacts of contamination. Peakall [33] defined a biomarker as "a biological response to a chemical or chemicals that gives a measure of exposure to, and sometimes also, of toxic cffect". The major strength of biomarkers lies in their potential to circumvent the serious limitations of the classical approach to environmental toxicology, that of measuring the residue of a chemical in either the organism or the environment and relating that to acute effects, through a more thorough understanding of toxicity mechanisms. The impact of environmental stress on faunas may be measured by responses at many scales and levels ranging from sub-cellular, to those of populations [30]. The two types of biomarker selected for the LOCS programme, come from either end of this scale: the neutralred retention assay, which monitors the response of subcellular organelles (lysosomes) to stress; and the measurement of coral community structure.

\subsection{Coral community structure}

Reef-building corals are popular for use as biomarkers of stress impacts in tropical coastal marine systems because of their sedentary, sessile and stenotypic nature [37]. They require relatively stable environmental conditions in order to survive, including levels of irradiance, salinity and temperature, which are tolerated to within only relatively narrow limits. Environmental perturbations as a result of anthropogenic impacts are therefore likely to affect reef corals before most other organisms. A number of studies have demonstrated the susceptibility of corals, and thcir communitics to anthropogenic perturbations [2, $11,25,26,47,56]$, although serious deleterious impacts are not universal $[3,14,41]$. The assessment of a coral reef community as a whole (including soft corals and algae) is considered to provide a more multivariate assessment than the study of corals alone, and may yield a broader insight into overall community change including community shifts and potentially more subtle changes than a loss of particular coral taxa.

\subsection{Neutral-red retention}

The structure and function of organisms, cells and organelles can be disturbed by toxic contaminants [30], though often the earliest detectable impacts of pollutants on marine organisms are associated with particular organelles, for example, lysosomes. Cellular responses to pollution-induced injury should provide rapid and highly sensitive indicators of environmental impact. It should also be possible to observe alterations in the structure or function of a target cell at an early stage of reaction to injury, before an integrated cellular response is manifest at the level of the whole physiological process. Several studies in recent years [23] have advocated the use of a neutral-red assay as a measure of cell damage. This makes use of the fact that only lysosomes in healthy cells can take up and retain the supravital dye, neutral red. The progress of dye uptake into the lyso-somes and, in the case of damaged cells, leakage back into the cytosol [23] can be monitored by microscope and quantified using time as the determinant of effect. Blood cells are relatively easy to obtain without harming the host and allow study of stress using in vitro methods. By field transplanting the animals it is possible to corroborate and validate performance of them under "laboratory conditions". It is important to measure performance in the natural environment because this is where the biological effects, if any, will occur. The main advantage of using transplanted animals over monitoring naturally settled populations is the experimental control, achieved by using animals of the same stock at all test sites.

\section{SETTING OF JAKARTA BAY AND TRANSECT}

Jakarta's conurbation is one of the largest in the world, occupying an area of $460 \mathrm{~km}^{2}$ and with a population of about 10 million. It is situated on the north Java coast, on the $500 \mathrm{~km}^{2}$ open embayment of Jakarta Bay (figure 1). Several rivers, with a combined catchment area of c. $2000 \mathrm{~km}^{2}$, form an integral part of the stormwater 
and sewage transport system within the urban centre. They discharge into the central sector of the bay, transporting with them sewage and industrial effluent containing a complex variety of pollutants $[21,46]$. The bay, defined by two flanking delta systems which supply large volumes of sediment to it, shelves at a low gradient seawards; waters within it do not exceed a depth of $20 \mathrm{~m}$. Within the bay a number of small coral islands occur, though to the northwest these pass into an extensive north-south chain of coral islands, the Pulau Seribu, or "Thousand Islands". Most of these have a lagoon and fringing reef; water depth between islands locally exceeds $50 \mathrm{~m}$.

The climatic cycle in northern Java is strongly controlled by the annual monsoon pattern. Total precipitation of approximately $1700 \mathrm{~mm} \mathrm{yr}^{-1}$ falls disproportionately during the west monsoon (November-March) with drier conditions occurring during the southeast monsoon (May-Sepember). The nearshore surficial currents in the bay are generally simple and flow at up to $0.5 \mathrm{~m} \mathrm{~s}^{-1}$ parallel to the coast and reflect surface wind-shear: during the west monsoon the prevaling currents flow eastwards, and during the southeast monsoon it flows westwards. The average daily air temperature range of Jakarta Bay is $23-33^{\circ} \mathrm{C}$, and that of the waters $23-31^{\circ} \mathrm{C}$, with maxima in the nearshore zone. A clear salinity gradient exists, mostly ranging from 31 near the shore, to 34 outside the bay [10], though at the height of the rains, salinities near points of discharge fall to 16 .

\subsection{The LOCS transect}

Prior to the LOCS programme the monitoring of contaminant levels in benthic faunas had been been undertaken by several researchers in Jakarta Bay $[4,5,15,43,44$, $48-51,54,55,57]$. Some studies, such as those of Harger and Sukarno [17] and Moll and Suharsono [29] suggested that coral reef communities around the islands increased in diversity and coral cover with increasing distance offshore. The LOCS transect was set up to establish the nature of this trend, and attempt to determine the relationship between land-based pollutants, interpreted by some as the cause of the trend [29] and health of the benthos.

The transect (figure 1) was oriented parallel with the expected gradient of contamination away from Jakarta during the southeasterly monsoons, though the suitability of substrates for study governed the exact location of study sites (table I). The coral community sites were all selected on the northeastern sides of islands between
Tanjung Priok, Jakarta's main port, and Pari Island, the southernmost of the islands in the Pulau Seribu chain. As coral communities between the Island of Ayer Besar and the port were poor, the impacts of anthropogenic influences in this interval were thus determined by transplanted mussel communities. Large clusters of farmed Perna viridis (L.) (shell lengths $35-45 \mathrm{~mm}$ ) attached to bamboo were collected from a fishery in Banten Bay (west of Jakarta Bay) with a small coastal population and little industry were allowed to depurate in flow-through aquaria for three days prior to field deployment. They were transplanted by suspension from moorings at between 1 and $3 \mathrm{~m}$ below chart datum and at least $2 \mathrm{~m}$ above the sea floor. All sampling was done within the southeasterly monsoon, the hydrochemical and sedimentological sampling in late June and July 1996, the biological monitoring in August and early September. The following sections describe the investigations into the contamination of the waters and sediments (section 3) and of animal tissues (section 4) along the transect, and the response of the fauna to the contamination (section 5).

\section{HYDROCHEMICAL AND GEOCHEMICAL SETTING}

\subsection{Methods}

To establish the hydrochemical and geochemical setting of the LOCS transect during the southeasterly monsoon, waters and sediments along the transect were sampled. In addition, water depth, and a range of oceanographic parameters, including temperature, oxygen saturation, $\mathrm{pH}$, and salinity were measured at $2 \mathrm{~m}$, using a pHOX ${ }^{\mathrm{TM}}$ model 902 sonde; the data are shown in figure 2. Water samples for chemical analysis were recovered from an average depth of $2 \mathrm{~m}$ using a Kemmerer sampler. Each was immediately decanted into an acid-washed PTFE reservoir, from which a volume of $0.5 \mathrm{~L}$ was pressure-filtered (at $20-40$ psi) through a $0.45 \mu \mathrm{m} \times 50 \mathrm{~mm}$ diameter cellulose acetate membrane into an $\mathrm{HNO}_{3}$ washed $\mathrm{HDPE}$ bottle. Water samples were acidified with $1 \% \mathrm{v} / \mathrm{v} \mathrm{HNO}_{3}$ within $6 \mathrm{~h}$ of collection. The cellulose acetate membrane was transferred to a Sterilin storage tube, air dried (at $60^{\circ} \mathrm{C}$ ) and weighed to assess the mass of SPM residue held upon it. Each was then placed in a sealed PTFE bomb and digested in $5 \mathrm{~mL} \mathrm{HNO}_{3}+2 \mathrm{~mL} \mathrm{HClO}_{4}+2 \mathrm{~mL}$ HF until a particulate-free solution remained. The water samples were analysed for heavy metals by anodic stripping voltammetry at the UK Environment Agency Labo- 


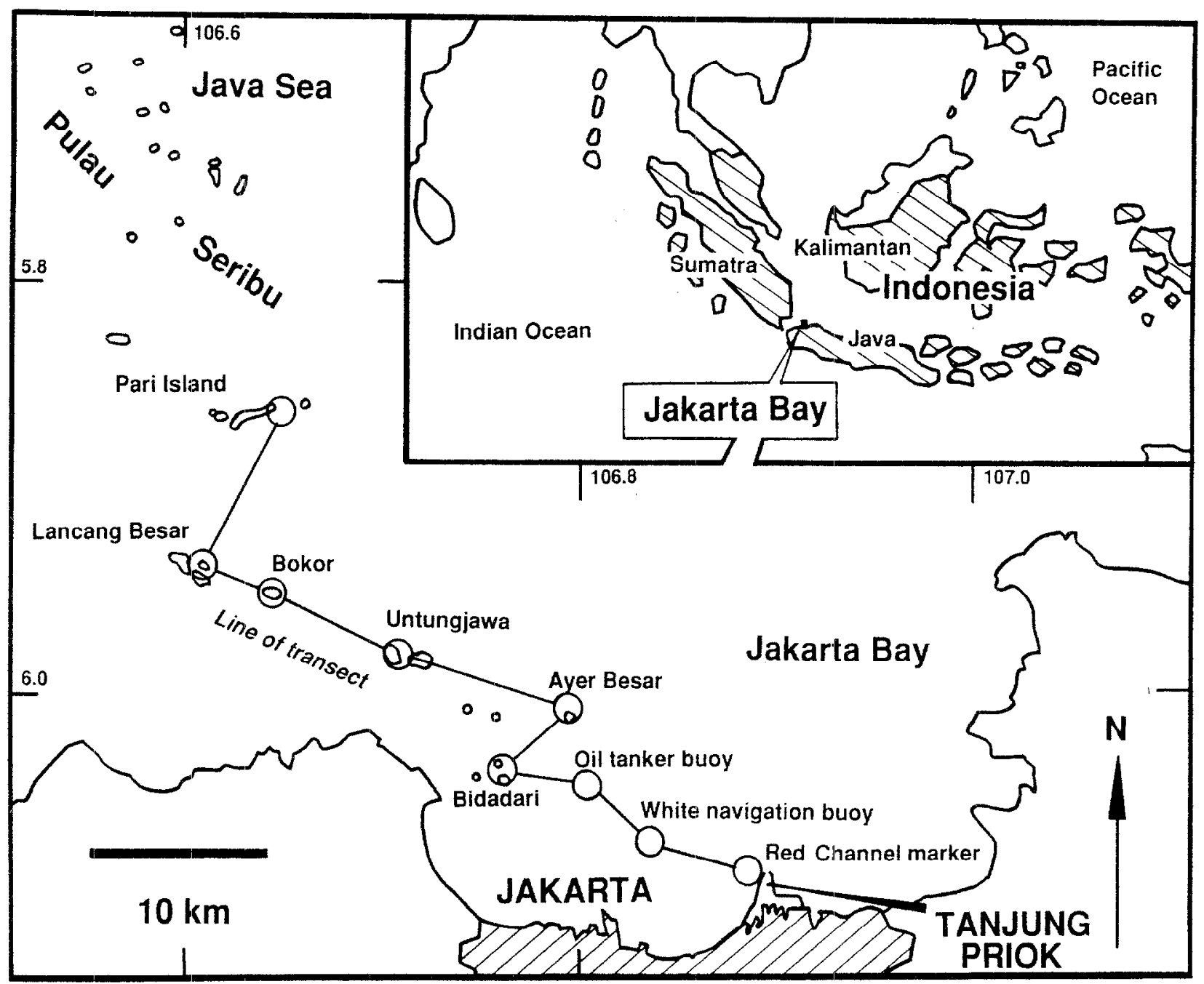

Figure 1. Location of the Land-Ocean Contamination Study (LOCS) transect in Jakarta Bay, Indonesia.

ratory, Llanelli, Wales; the digested membrane solutions were analysed by ICP-MS. All element associations were determined by Pearson correlation analysis.

Muds were mostly sampled using a $1.1 \mathrm{~m}$ pneumatic piston corer [60]. A Van Veen grab sampler was mostly used to collect sandy sediments. Samples were transported to the UK in securitainers. Aliquots for geochemical analysis were dried at $60^{\circ} \mathrm{C}$, disaggregated and sieved to $150 \mu \mathrm{m}$ (100 BSI mesh) prior to analysis. A sub-sample of approximately $2 \mathrm{~g}$ mass was used to determine ignition loss [60], the rest was used to produce pressed pellets of c. $12 \mathrm{~g}$ mass for the subsequent determination of range of metals by X-ray fluorescence (XRF).

\subsection{Results}

The distributions of metals in solution and SPM have broadly similar patterns along the transect. No clear onshore trend occurs, and the greatest concentrations occur offshore (e.g. Cu, figure 3). The extent of spatial covariation between the fractions are, however, not representative of the bay as a whole. Although statistically significant covariation occurs with respect to $\mathrm{Pb}$ and $\mathrm{Cu}$, the apparent relationship between the dissolved and particulate fractions for other metals, such as $\mathrm{Cr}$ or $\mathrm{Zn}$ is not significant [60]. By way of contrast, the distribution of metals in the seabed sediments shows a general 
Table I. Location of sites along the LOCS transect.

\begin{tabular}{|c|c|c|c|c|c|}
\hline $\begin{array}{l}\text { Distance } \\
\text { from } \\
\text { Port }\end{array}$ & Site name & $\begin{array}{l}\text { LOCS } \\
\text { Site } \\
\text { no.* }\end{array}$ & $\begin{array}{l}\text { Water \& } \\
\text { sediment } \\
\text { study site }\end{array}$ & $\begin{array}{l}\text { Perna } \\
\text { viridis } \\
\text { study site }\end{array}$ & $\begin{array}{l}\text { Coral } \\
\text { community } \\
\text { study site }\end{array}$ \\
\hline $2 \mathrm{~km}$ & $\begin{array}{l}\text { Red channel } \\
\text { marker }\end{array}$ & 37 & $\begin{array}{l}06.04 .42 \mathrm{~S} \\
106.52 .34 \mathrm{E}\end{array}$ & $\begin{array}{ll}06.04 .15 & \mathrm{~S} \\
106.51 .42 \mathrm{E} & \\
\end{array}$ & $\begin{array}{l}\text { Poor coral } \\
\text { communities }\end{array}$ \\
\hline $5 \mathrm{~km}$ & $\begin{array}{l}\text { White navigation } \\
\text { buoy }\end{array}$ & 1 & $\begin{array}{l}06.03 .19 \mathrm{~S} \\
106.50 .10 \mathrm{E}\end{array}$ & $\begin{array}{|cc|}06.03 .93 & S \\
106.49 .66 \mathrm{E} & \\
\end{array}$ & $\begin{array}{l}\text { Poor coral } \\
\text { communities }\end{array}$ \\
\hline $10 \mathrm{~km}$ & $\begin{array}{l}\text { Large oil tanker } \\
\text { buoy }\end{array}$ & 2 & $\begin{array}{l}06.02 .04 \mathrm{~S} \\
106.48 .34 \mathrm{E} \\
\end{array}$ & $\begin{array}{ll}06.02 .35 & \mathrm{~S} \\
106.47 .62 \mathrm{E} & \\
\end{array}$ & $\begin{array}{l}\text { Poor coral } \\
\text { communities }\end{array}$ \\
\hline $15 \mathrm{~km}$ & $\begin{array}{l}\text { Bidadari } \\
\text { (Island) }\end{array}$ & 41 & $\begin{array}{l}06.01 .90 \mathrm{~S} \\
106.44 .15 \mathrm{E} \\
\end{array}$ & \begin{tabular}{|c|}
$06.01 .65 \mathrm{~S}$ \\
$106.44 .96 \mathrm{E}$
\end{tabular} & $\begin{array}{l}\text { Poor coral } \\
\text { communities }\end{array}$ \\
\hline $16 \mathrm{~km}$ & $\begin{array}{l}\text { Ayer Besar } \\
\text { (Island) }\end{array}$ & 24 & $\begin{array}{l}06.00 .10 \mathrm{~S} \\
106.47 .05 \mathrm{E} \\
\end{array}$ & 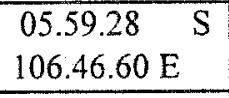 & $\begin{array}{l}06.00 .02 \mathrm{~S} \\
106.46 .09 \mathrm{E}\end{array}$ \\
\hline $21 \mathrm{~km}$ & $\begin{array}{l}\text { Untungjawa } \\
\text { (Island) }\end{array}$ & 22 & $\begin{array}{l}05.58 .09 \mathrm{~S} \\
106.40 .54 \mathrm{E} \\
\end{array}$ & $\begin{array}{l}\text { No mussels } \\
\text { transplanted }\end{array}$ & $\begin{array}{l}05.58 .42 \mathrm{~S} \\
106.42 .33 \mathrm{E} \\
\end{array}$ \\
\hline $30 \mathrm{~km}$ & $\begin{array}{l}\text { Bokor } \\
\text { (Island) }\end{array}$ & 26 & $\begin{array}{l}05.55 .27 . \mathrm{S} \\
106.41 .10 . \mathrm{E} \\
\end{array}$ & $\begin{array}{l}\text { No mussels } \\
\text { transplanted }\end{array}$ & $\begin{array}{l}05.56 .62 \mathrm{~S} \\
106.37 .61 \mathrm{E} \\
\end{array}$ \\
\hline $70 \mathrm{~km}$ & $\begin{array}{l}\text { Lancang Besar } \\
\text { (Island) }\end{array}$ & $\begin{array}{l}44 ! \\
20 \\
\end{array}$ & $\begin{array}{l}05.55 .30 \mathrm{~S} \\
106.35 .00 \mathrm{E} \\
\end{array}$ & $\begin{array}{l}\text { No mussels } \\
\text { transplanted }\end{array}$ & $\begin{array}{l}05.55 .61 \mathrm{~S} \\
106.35 .50 \mathrm{E}\end{array}$ \\
\hline $72 \mathrm{~km}$ & $\begin{array}{l}\text { Pari } \\
\text { (Island) }\end{array}$ & 27 & $\begin{array}{l}05.52 .00 \mathrm{~S} \\
106.37 .16 \mathrm{E} \\
\end{array}$ & $\begin{array}{l}05.54 .69 \mathrm{~S} \\
106.37 .25 \mathrm{E} \\
\end{array}$ & $\begin{array}{l}05.51 .00 \mathrm{~S} \\
106.37 .95 \mathrm{E} \\
\end{array}$ \\
\hline
\end{tabular}

shoreward increase in all of the metals mapped out (figures 3,4 ). The distributions around the bay confirm such patterns [60], though recognise that high levels of $\mathrm{Cr}$ and $\mathrm{Ni}$ extend from land-based sources, seawards, for many kilometres.

\subsection{Discussion}

The distributions of metals in waters recorded during the LOCS surveys are more suggestive of control by hydrodynamic regime than source proximity. Although previous hydrographic investigations $[10,22,53]$ have suggested that the oceanographic setting of Jakarta Bay is simple, this is not borne out by the findings of the LOCS programme, which suggest that the residence time of waters in the central bay may be longer than previously recognised. The estabished, yet simplistic, circulation models, based almost exclusively on surface and nearsurface data, have also been questioned in the light of new oceanographic measurements collected by LIPI which suggest a complex, stratified system exists in the bay. Biogeochemical assimilation of metals such as $\mathrm{Pb}$, $\mathrm{Zn}$ and $\mathrm{Cu}$ results in the concentration of these being greatest in mid-bay waters with highest residence times, not only with respect to the dissolved fraction, but also

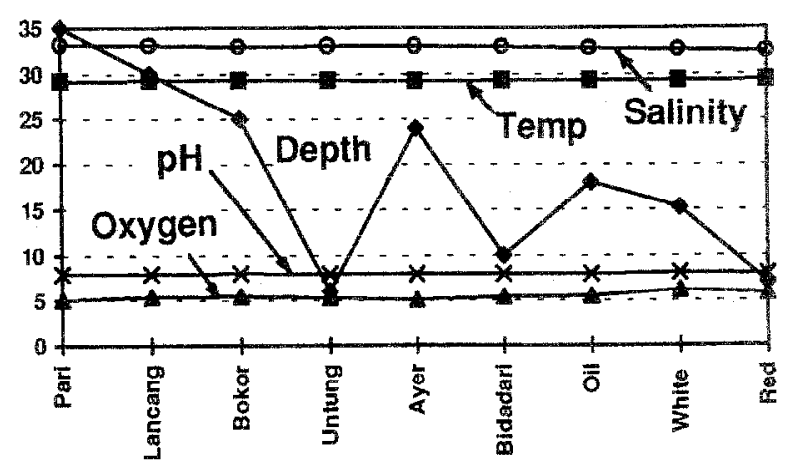

Figure 2. Physico-chemical character of the LOCS transect. Oxygen in $m g L^{-1}$, depth in $m$, temperature in ${ }^{\circ} \mathrm{C}$ and salinity is dimensionless.

SPM. The very poor correlation between concentrations of $\mathrm{Pb}, \mathrm{Zn}$ and $\mathrm{Cu}$ in seawater and sea bed sediments along the transect suggests that the hydrochemical patterns recognised are only seasonal. The distribution of the metals in the sea bed sediments is likely to reflect seasonally averaged metal loadings. The wider LOCS survey [60] shows that the sources of these may differ; $\mathrm{Pb}$ is dominantly sourced near Tanjung Priok, whilst $\mathrm{Cu}$ and $\mathrm{Zn}$ are widely sourced from the central and southwestern shore of Jakarta Bay. 

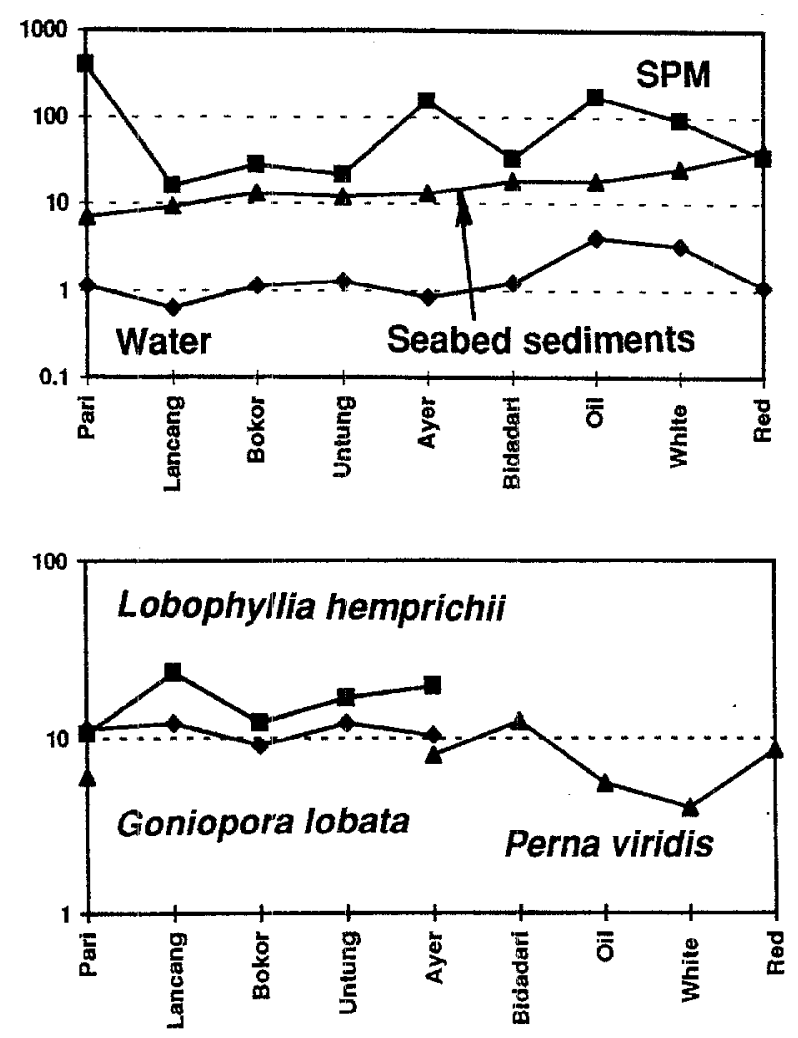

Figure 3. Concentrations of $\mathrm{Cu}$ in water, sediments and animal tissues (ppm) along the LOCS transect. The upper part shows distributions of $\mathrm{Cu}$ in solution, in SPM and seabed sediments. The lower part shows mean distributions of $\mathrm{Cu}$ in the tissues of the corals Lobophyllia hemprichii and Goniopora lobata, and the mussel, Perna viridis.

The patterns of Cr and Ni in solution, SPM and sea bed sediments suggests that the distribution of these is controlled largely by influx from estuaries as the main concentrations occur near such sources [60]. It is difficult to differentiate the anthropogenic $\mathrm{Cr}$ and $\mathrm{Ni}$ loadings from background levels.

\section{UPTAKE OF CONTAMINANTS BY CORAL AND MUSSEL TISSUES}

The metal content of coral and mussel tissue was measured to give an indirect assessment of stress caused by contamination. The lack of suitable habitats along the transect prevented the sampling of both coral and mussel tissues at all sites.

\subsection{Methods}

Five colonies of each of Goniopora lobata Edwards and Haime and Lobophyllia hemprichii Ehrenberg were


Figure 4. Concentrations of $\mathrm{Zn}$ in water, sediments and animal tissues (ppm) along the LOCS transect. The upper part shows distributions of $\mathrm{Zn}$ in solution, in SPM and seabed sediments. The lower part shows mean distributions of $\mathrm{Zn}$ in the tissues of the corals Lobophyllia hemprichii and Goniopora lobata, and the mussel, Perna viridis.

removed from each coral survey site, and transported in seawater to the laboratory (within three hours of collection). Tissues were removed using a high pressure airgun [39] and placed in $50 \%$ nitric acid-washed containers for transport to the UK in dry ice. The tissue samples were dried for $48 \mathrm{~h}$ at $60^{\circ} \mathrm{C}$, weighed, and then digested in $3 \mathrm{~mL} 69 \%$ nitric acid. Mussels (Perna viridis) were sampled after 14 days transplantation; at the Ayer Besar or Bidadari sites, the transplanted mussels had been removed (lost), so native individuals (local population) were used. The mussels were allowed to depurate their guts for $24 \mathrm{~h}$ prior to sampling for metal analysis. Softtissues were removed from the shells with stainless steel equipment and the byssus discarded. Tissues were ovendried at $105^{\circ} \mathrm{C}$ and returned to the UK where they were manually homogenised and digested in $2 \mathrm{~mL}$ of concentrated nitric acid. Digests were then evaporated for $5 \mathrm{~h}$ at $100{ }^{\circ} \mathrm{C}$ followed by $2 \mathrm{~h}$ at $120^{\circ} \mathrm{C}$, and the residues leached with $1 \mathrm{~cm}^{3}$ of $50 \% \mathrm{HCl}$ at $50^{\circ} \mathrm{C}$ for $2 \mathrm{~h}$. Both coral and mussel tissue digests were made up to a final known volume with deionised water prior to analysis for 
metals by inductively-coupled plasma mass spectrometry (ICP-MS).

\subsection{Results}

Analysis of the heavy metal concentrations in the invertebrate tissues showed no significant differences in the relative concentrations of metals, by element or in total, between individuals at the same site (in the case of corals), or between sites. No significant relationship was noted between the concentration of any of the metals analysed with distance offshore (figures 3,4 ). The transplanted mussels had low mean concentrations of $\mathrm{Cu}$ $\left(<10 \mu \mathrm{g} \mathrm{g}^{-1}\right.$ dry weight) similar to those reported by other workers from uncontaminated locations [8]. The range of $\mathrm{Zn}$ concentrations measured was much narrower compared with the other metals. The coefficient of variation at each site was also small $(<20 \%)$.

\subsection{Discussion}

The distribution of metals in the corals and mussels appears to related to metal concentrations both in solution and SPM. On the basis of the few measurements made in the LOCS surveys it appears that an inverse relationship exists between metal concentration in tissues of Lobophyllia hemprichii, and metal-loadings in seawater. The same may be true of Perna viridis, in relation to $\mathrm{Cu}$ (though see below). The accumulation rate of a metal will depend on the rates of metal uptake and metal excretion that the animal is able to execute, and these (particularly uptake rates [1]) are likely to change with the concentration of metal exposure. In corals, it is likely that the type and abundance of endosymbiotic algae (zooxanthellae) has a greater influence on tissue metal concentrations than environmental metal loads [18, 19]. All aquatic organisms take up metals in significant quantities, but for many species the excretion of accumulated metals may be insignificant. Philips and Rainbow [36] presented a review table of aquatic organism metal accumulation strategies in which bivalve molluses such as Perna viridis were included as non-regulators of most metals such as $\mathrm{Cu}, \mathrm{Fe}, \mathrm{Mn}, \mathrm{Pb}$ and $\mathrm{Zn}$ (when in the form of granules), and rarely as regulators of $\mathrm{Cu}$ and $\mathrm{Zn}$ overall. It has been shown to accurately reflect the distribution of most metals in Hong Kong waters, although it partially regulates the contents of $\mathrm{Zn}$ in its soft tissues [6,7]. It has also been shown [35] to be a capable biomonitor of organochlorine pesticides and PCBs.

\section{MONITORING STRESS OF FAUNAS USING BIOMARKERS}

\subsection{Methods}

\subsubsection{Coral community structure}

For the quantitative assessment of coral community, three replicate $10 \mathrm{~m}$ line transects at $8 \mathrm{~m}, 4 \mathrm{~m}$ and $2 \mathrm{~m}$ depth below chart datum were used at each site. Live coral cover, number of coral colonies, number of genera, total live hard coral cover of different growth forms (i.c. branching, massive, plating), macro-algal cover, soft coral cover and the cover of the urchin Diadema sp. were recorded along each transect. Cover (figure 5) was determined by recording the intersected length in plan view of the living organism [47]. Corals were determined to generic level. Colonies growing independently of other colonies were determined as separate $[24,27]$. Where colonies are divided, by partial mortality, into separate units they were recorded as parts of the same colony but only the live coral cover was recorded [12, 27, 47]. Data analysis was carried out using the PRIMER and MiniTab software packages in conjunction with Clarke and Warwick [9]. Following Warwick et al. [57] and Tomaseik and Sander [47], total hard coral cover based on the cover of each genus on each transect was analysed using the multivariate PRIMER MDS technique, followed by a 1 way-ANOSIM test. Univariate measures (KruskalWallis) were also conducted on species richness (Margalef's d), Shannon diversity ( $\left.H^{\prime}\right)$, evenness (Pielou's J) and Simpson's dominance index (D), from the total hard coral cover data, using logarithms to the base e. Total cover of soft corals, hard corals, macro-algae and Diadema sp., referred to as life-form categories for each site were measured using MDS, ANOSIM and KruskalWallis analyses due to uneven variances. Data analysis using the PRIMER software, involved the transformation of the community data by way of a square-root transformation, and heavy metal data using a log transformation. Using the total coral cover data for each genus, $k$-dominance curves were constructed for the totals of the replicates at $8 \mathrm{~m}, 4 \mathrm{~m}$ and $2 \mathrm{~m}$ depth at each site.

\subsubsection{Neutral-red retention}

Twenty mussels were collected for the neutral-red retention assay from each location after 14 and 20 days following transplantation. Their valves were prised apart with a scalpel and $0.5 \mathrm{~mL}$ of haemolymph withdrawn from the anterior adductor muscle into a $2.5 \mathrm{~mL}$ hypodermic 


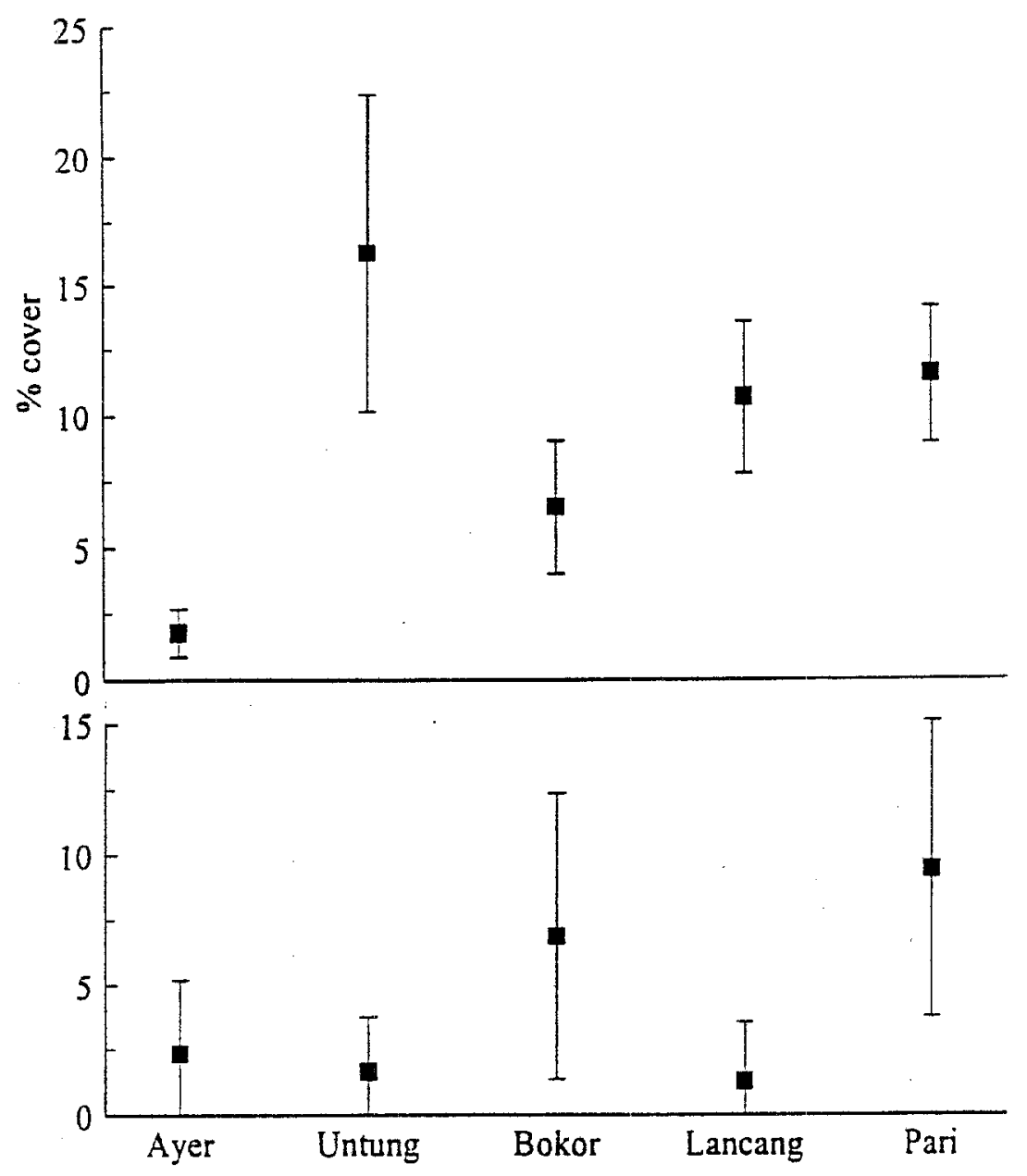

Figure 5. Cover of coral genera at a depth of $2 \mathrm{~m}$ at sites on the LOCS transect.

syringe fitted with a 25 gauge needle and containing $0.5 \mathrm{~mL}$ of physiological saline and discharged into a $2 \mathrm{~mL}$ siliconised Eppendorf tube. A stock solution of neutral red was made by dissolving $20 \mathrm{mg}$ of dye in $1 \mathrm{~mL}$ of Dimethyl sulphoxide. A working solution, renewed every hour, was then prepared by diluting $10 \mu \mathrm{L}$ of the stock solution with $2.5 \mathrm{~mL}$ of a mussel physiological saline [34]. Haemolymph samples $(20 \mu \mathrm{L})$ were placed on a microscope slide, and the cells allowed to adhere for 3 min (in a darkened humidity chamber) before application of the neutral-red working solution $(20 \mu \mathrm{L})$ and a coverslip. To ensure the process of haemolymph extraction and subsequent handling did not seriously injure the cells, an Eosin $Y$ test [58] was undertaken. Each slide was continuously scanned at random under a microscope to observe the appearance of the cells. Each visualisation was divided into three minute intervals from which the number of cells with fully stained cytosols and the number of cells with unstained cytosols were determined. Observation was stopped when the ratio of cells with fully stained cytosols was $>50 \%$ of the total number of cells counted. This interval was recorded as the neutral-red retention time (later NRR-time; [45]). The data were analysed statistically for differences in NRR-times and metal concentrations using Analysis of Variance a priori to test for differences amongst all means. When differences were found among groups, Tukey's post hoc test was used to determine differences between specific groups.

\subsection{Results}

The full results of the coral community surveys are presented by Weeks et al. [58], though a summary of the results is given in table II. 

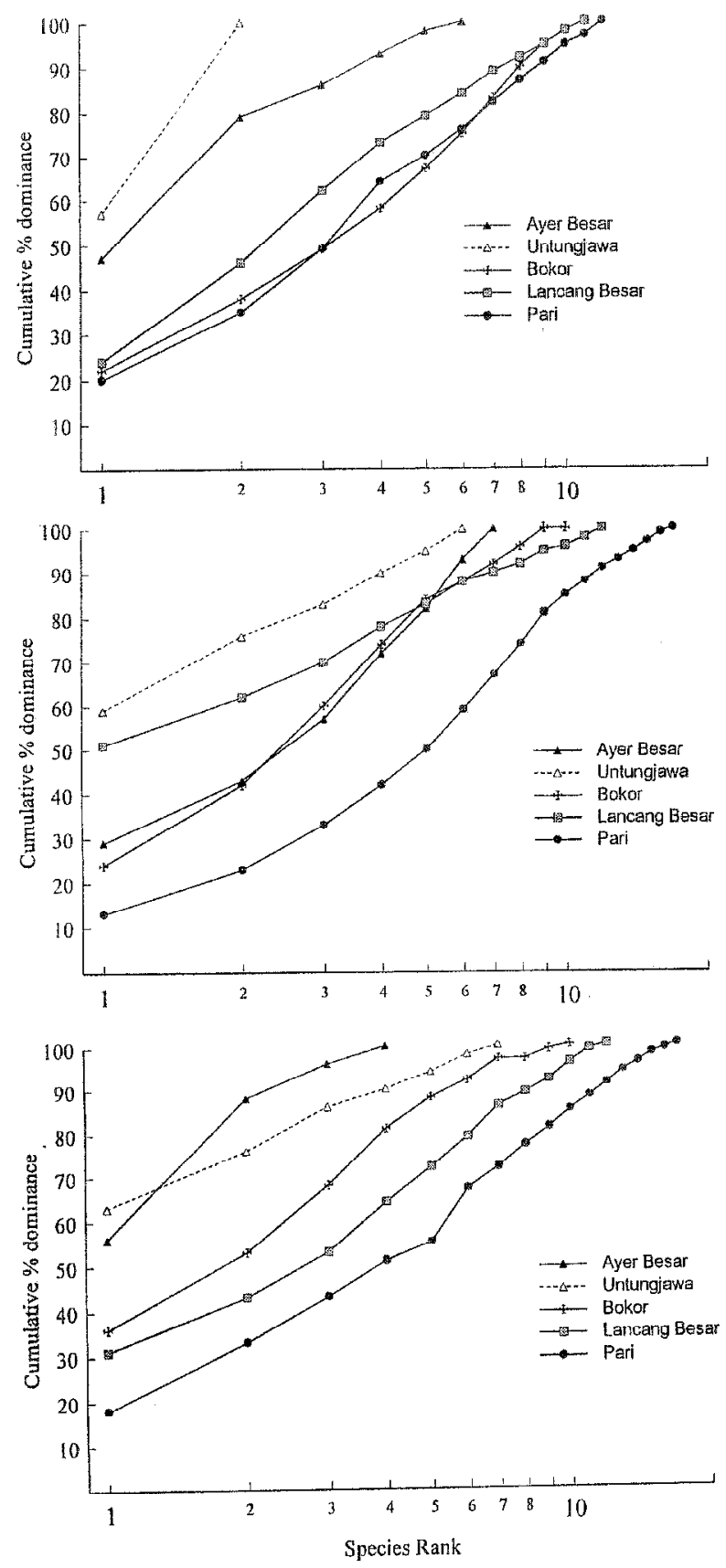

Figure 6. $k$-dominance curves, based on the coral community surveys at each site $( \pm 1 \mathrm{SD})$. Top, massive corals; bottom, branching corals.

The $k$-dominance curves for the $8 \mathrm{~m}$ and $2 \mathrm{~m}$ depths clearly show a separation of the five sites (figure 6). The sites closest to the coast of Jakarta Bay (Ayer and Untungjawa) show a higher level of dominance and lower generic diversity at $8 \mathrm{~m}$ depth. At the $4 \mathrm{~m}$ depth the sep- aration of sites is not as striking as for the other two depths. This seems to be mainly due to a relatively high generic diversity and correspondingly low level of dominance at Ayer Besar. The $k$-dominance plot for the $2 \mathrm{~m}$ depth shows a clear gradation in increasing generic diversity with increasing distance from the coast of Jakarta Bay with a corresponding decrease in dominance.

The neutral-red retention assay indicated that whilst blood cell lysosomes from the reference population (Banten Bay) had the capacity to retain the dye for up to $60 \mathrm{~min}$ (when observation was stopped), those collected from natural populations closer to the harbour entrance lost the dye to the cytosol between 10 and $25 \mathrm{~min}$ after dye exposure. Recovery of field-transplanted mussels met with limited success, though those recovered after 14 days (figure 7) showed a similar, but less marked pattern in neutral-red response than the natural population. After 20 days only two transplanted populations were recovered, both from close proximity to the harbour entrance and these mussels exhibited severely shortened retention times $(5 \mathrm{~min})$. All native populations from which it was possible to collect samples also exhibited reduced retention times in contrast to those measured after only 14 days. There was a gradient of response towards significantly longer retention times as one moved away from close proximity to Jakarta harbour. An overall decrease in the total volume of extractable blood cells from mussels was also noted as one moved towards the harbour entrance.

\subsection{Discussion}

The significant increase in diversity of coral genera, increasing coral cover, based on the cover of genera, and coral colony number at the $2 \mathrm{~m}$ sampling depth, and NRR-time exhibited by mussels, associated with distance from the Tanjung Priok unambiguously shows that the faunas in Jakarta Bay are stressed in nearshore settings. Whilst the health of coral communities has been influenced by natural stresses such as grazing by the Crown of Thorns starfish, Acanthaster [38] or bleaching by El Nino Southern Oscillation events $[4,42,57]$, it is more likely that the stresses measured by both coral and mussel biomarkers are associated with human activities [29, 31]. These include fishing, coral mining $[15,32,49$, $50,54]$, dredging, boat activities, oil spills, construction and discharges of industrial and domestic effluents with high metal content [40]. 
Table I. Summary of statistical analysis investigating whether any significant differences $(\mathrm{p}<0.05 \%$ ) exist between the coral study sites. $\checkmark=$ Significant, $1 \mathrm{wA}=1$ way ANSIOM test, $\mathrm{K}-\mathrm{W}=$ Kruskal-Wallis test

\begin{tabular}{|l|l|l|l|l|}
\hline Variable & Test & 2m depth & 4m depth & 8m depth \\
\hline Coral genera cover & IwA & $\checkmark$ & & \\
\hline Total cover of life forms & 1wA & $\checkmark$ & $\checkmark$ & $\checkmark$ \\
\hline Hard coral cover at depth & K-W & & & \\
\hline Cover of Diadema sp. & K-W & $\checkmark$ & & \\
\hline Soft coral cover & K-W & & & \\
\hline Macro algal cover & K-W & $\checkmark$ & & $\checkmark$ \\
\hline Number of coral colonies & K-W & $\checkmark$ & $\checkmark$ & \\
\hline Diversity (H') of coral & K-W & $\checkmark$ & & $\checkmark$ \\
\hline Evenness (Pielou J) of coral & K-W & & & \\
\hline Richness (Margalef's d) of coral genera & K-W & & & \\
\hline Simpson's dominance of coral genera & K-W & & & \\
\hline Branching coral cover & K-W & $\checkmark$ & & \\
\hline Plating coral cover & K-W & & $\checkmark$ & $\checkmark$ \\
\hline Massive coral cover & K-W & $\checkmark$ & & $\checkmark$ \\
\hline
\end{tabular}

Figure 7. Mean neutralred retention times in minutes $( \pm 1$ SD) in lysosomes from the green mussel (Perna viridis) measured after 14 days transplantation. Banten Bay was the site of the original transplant population. The solid bars represent mussels recollected after the transplant, the open bars mussels harvested from natural populations.

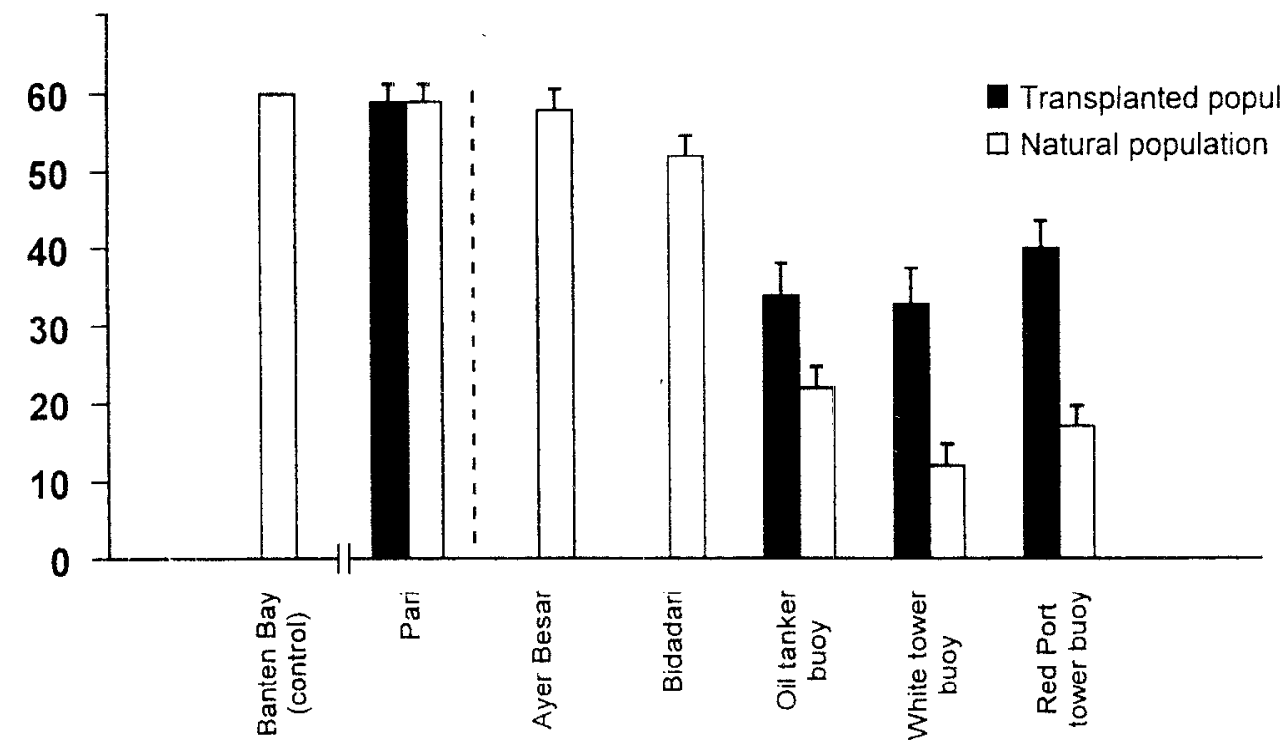

The transect of community structure in the coral community studies appears to mirror the concentration gradient of metals in the sea bed sediments (figures 3,4). This correlation may be used to imply that faunas are controlled principally by seasonally-averaged metal levels in Jakarta Bay. The mussels, however, show a poor correlation between the metal content of their tissues in relation to the gradient recognised in the NRR studies. The relatively low concentration of metals in waters and SPM

near the harbour suggests that metal contaminants are not the primary cause of stress.

This raises the question about what factors are causing the biomarker responses measured in the corals and mussels on the LOCS transect. The reduction in water transparency by suspended particulate matter may influence many faunal groups, and is critical for corals. Tomascik et al. [48] showed a clear decrease in the water quality 
and water transparency (critical for coral survival) between 1928 and 1933. Umbgrove [52] believed that the reduction in water transparency has resulted in a complete absence of 'functional coral reefs' from the inner islands of Jakarta Bay, which were present in 1939. The reduction in water transparency is also likely to result Irom suspended terrigenous sediments and from phytoplankton blooms, caused by increased nutrient concentrations $\left(\mathrm{PO}_{4}, \mathrm{NO}_{3}\right)$ in the bay [48]. The blooms, which are now spreading further offshore, from $2 \mathrm{~km}$ offshore in 1982 to $12 \mathrm{~km}$ offshore in 1990 [16], oflen develop rapidly. One such sudden bloom occurred part way through the second collection of mussels (5 September 1996) and may explain the dramatic decline in neutral-red retention times measured for all mussels during this second sampling (after 20 days in the field). Water samples taken during this period showed phytoplankton abundance as high as 7000000 individuals per litre [the population consisting of Chaetoceros $55 \%$, Skeletonema (32\%) Noctiluca scintilans $(7 \%)$, Coscinodiscus (1\%) and others comprising $5 \%$. It is tentatively considered here that increased turbidity, combined with the presence of greater concentrations of organic chemical contaminants, in inshore waters were the main factors which contributed to the biomarker response of the faunas.

The LOCS surveys illustrate well the main drawback of marine biomarker assessments: the task of identifying the causal factors which relate to detected impacts as the distribution and survival of faunas is determined by the net effect of many interrelated environmental factors. Many such environmental factors may well act additively and/ or synergistically. A statistically significant relationship does not prove an environmentally significant relationship. Conversely, not finding a statistically significant relationship could be attributed to the influence of various other biological and abiotic factors.

\section{CONCLUSIONS}

Distributions of metals in solution, in SPM and in tissues of benthic animals within Jakarta Bay were broadly similar; they do not show an onshore concentration gradient. It is likely that the concentration of metals in the tissues of the corals and mussels is governed principally by hydrochemistry.

The biomarker surveys indicated increasing environmental stress nearshore. Whilst this trend parallets the seasonally averaged distribution of metals (shown by the metal concentrations of sea bed sediments that increased shorewards), it is considered more likely that the biomarkers were responding principally to other near-shore stresses. such as sediment and nutrient loading of water, and/or organic contamination, both sewage and hydrocarbons.

The studies on the LOCS transect illustrate well the problems of relating hydrochemistry, geochemistry and tissue chemistry to stress in benthic communities, that of isolating the significant environnental factors (including anthropogenic contamination) which have an impact upon them.

\section{Acknowledgements}

The authors wish to thank the many members of staff involved in the LOCS programme, at all participating institutes, for their assistance in sampling, data preparation and analysis. Funding for the programme was provided by the UK Overseas Development Administration under R and D contract R6191. This paper is published with the permission of the Director of the British Geological Survey (Natural Environment Research Council).

\section{REFERENCES}

[1] Baden S.P., Eriksson S.P., Weeks J.M., Uptake, accumulation and regulation of manganese during experimental hypoxia and normoxia by the decapod Nephrops norvegicus (L.), Mar. Poll. Bull. 31 (1995) 93-102.

[2] Bak R.P.M., Lethal and sublethal effects of dredging on reef corals, Mar. Poll. Bull. 9 (1978) 14-16.

[3] Brown B.E., Holley M.C., Metal levels associated with tin dredging and smelting and their effects upon intertidal reef flats at Ko Phuket, Thailand, Coral Reefs 1 (1982) 131-137.
[4] Brown B.E., Suharsono., Damage and recovery of coral reefs affected by El Nino related sea water warming, in the Thousand Islands, Indonesia, Coral Reefs 8 (1990) 163-170.

[5] Brown B.E., Holley M.C., Sya'rani and Le Tissier M.D.A., Coral assemblages of reef flats around Pulau Pari, Thousand Islands, Indonesia, Atoll Res. Bull. 281 (1983) 1-14

[6]. Chan, H.M., Accumulation and tolerance to cadmium, copper, lead, and zinc by the green mussel Perna viridis, Mar. Ecol. Prog. 48 (1988a) 295-303. 
[7] Chan H.M., A survey of trace metals in Perna viridis (L.) (Bivalvia: Mytilacea) from the coastal waters of Hong Kong, Asian Mar. Biol. 5 (1988b) 89-102.

[8] Chan H.M., Temporal and spatial fluctuations in trace metal concentrations in transplanted mussels in Hong Kong, Mar. Poll. Bull., 20 (1989) 82-86.

[9] Clarke K.R., Warwick R.M., Change in marine communities: An approach to statistical analysis and interpretation, NERC, Plymouth Marine Laboratory, UK (1994).

[10] Delft Hydraulics Laboratory, Coastal zone information system and water quality modelling for management of coastal waters, BTA-60, Rep. RI 182, Delft, NL (1985).

[11] Dodge R.E., Vaisnys J.R., Coral populations and growth patterns: response to sedimentation and turbidity associated with dredging, J. Mar. Res., 35 (1977) 715-730.

[12] Dodge R.E, Logan A., Antonius A., Quantitative reef assessment studies in Bermuda: a comparison of methods and preliminary results, Bull. Mar. Sci., 32 (1982) 745-760.

[13] Dodge R.E., Gilbert T.R., Chronology of lead pollution contained in banded coral skeletons, Mar. Biol. 82 (1984) 9-13.

[14] Dollar S.J., Grigg R.W., Impact of a kaolin spill on a coral reef in Hawaii, Mar. Biol. 65 (1981) 269-276.

[15] Hardenberg J.D.F., De koraaleilanden in de Baai van Batavia, Verslag Ned. Indische Ver. Natuurbesch. 11 (1939) 234-242.

[16] Harger J.R.E., Environmental trends and reef monitoring strategies, Proc. 7th Int. Coral Reef Symp., Guam, 1992.

[17] Harger J.R.E. Sukarno, Preliminary account of coral reef structure and coral populations in the inner islands of the Pulau Seribu chain, Unesco, Jakarta, 1985, 1-10

[18] Harland A.D., Bryan G.W. Brown B.E., Zinc and cadmium absorbtion in the symbiotic anemone Anemonia viridis and the non symbiotic anemone Actinia equina, J. Mar. Biol. Ass. UK 70 (1990) 789-802.

[19] Harland A.D. Brown B.E., Metal tolerance in the scleractinian coral Porites lutea, Mar. Poll. Bull. 20 (1989) 353-357.

[20] Howard L.S. Brown B.E., Heavy metals and reef corals, Oceanogr. Mar. Biol. Ann. Rev. 22 (1984) 195-210.

[21] Hutagalung H.P. Razak H., Pengmatan pendahuluan kadar $\mathrm{Pb}$ dan Cd dalam air dan biota di estuaria Muara Angke, (Preliminary investigations of $\mathrm{Pb}$ and $\mathrm{Cd}$ content in water and marine organisms in the Angke estuary), Oceanologi Indon. 15 (1982) $1-10$.

[22] IFIAS-ABC., Coastal and ocean resources management: A framework for analysis, Delft, 1982.

[23] Lowe D.M., Moore, M.N., Evans, B.M., Contaminant impact on interactions of molecular probes with lysosomes in living hepatocytes from dab, Limanda limanda, Mar. Ecol. Prog. 91 (1992) 135-140.

[24] Loya Y., Community structure and species diversity of hermatypic corals at Eilat, Red Sea, Mar. Biol. 13 (1972) 100-123.

[25] Loya Y., Possible effects of water pollution on the community structure of Red Sea corals, Mar. Biol. 29 (1975) 177-185.
[26] Loya Y., Effects of water turbidity and sedimentation on the community structure of Puerto-Rican corals, Bull. Mar. Sci. 26 (1976) 450-466.

[27] Loya Y., Plotless and line transect methods, in: Stoddart D.R., Iohannes R.F. (Fils.), Coral reefs: research methods, Unesco, Paris, 1978, 197-217.

[28] McConchie D., Harriot V.J., The partitioning of metals between tissue and skeletal parts of corals: Application in pollution monitoring, Proc. 7th Intern. Coral Reef Symp., Guam 1 (1992) 97-103.

[29] Moll H. Suharsono, Distribution, diversity and abundance of reef corals in Jakarta Bay and Kepulauan Seribu, in: Brown B.E. (Ed.), Human induced damage to coral reefs: Results of a regional Unesco (COMAR) workshop with advanced training Unesco Rep. Mar. Sci., France 40 (1986) 180 p.

[30] Moore M.N., Cellular responses to pollutants, Mar. Poll. Bull., 16 (1985) 134-139.

[31] Ongkosongo O.S.R., Some harmful stresses to the Seribu coral reefs, Indonesia, in: Proceedings of MAB-COMAR Regional Workshop on Coral Reef Ecosystems: Their Management Practices and Research/Training needs, Unesco: MABCOMAR and LIPI, Jakarta, 1986, 133-142.

[32] Ongkosongo O.S.R. Sukarno, in Brown B.E. (Ed.), Background to the study sites in the Bay of Jakarta and Kepulauan Seribu, Results of a regional Unesco (COMAR) workshop with advanced training, Unesco Rep. Mar. Sci., France, 40 , 1986, $180 \mathrm{p}$.

[33] Peakall D.B., The role of biomarkers in environmental assessment, 1. Introduction, Ecotoxicology 3 (1994) 157-160.

[34] Peek K., Gabbot P.A., Adipogranular cells from the mantle tissue of Mytilus edulis L. 1. Isolation, purification and biochemical characteristics of dispersed cells, J. Exp. Mar. Biol. Ecol. 126 (1989) 203-216.

[35] Phillips D.J.H., Organochlorines and trace metals in green-lipped mussels Perna viridis from Hong Kong waters: a test of indicator ability, Mar. Ecol. Prog. 21 (1985) 251-258.

[36] Phillips D.J.H., Rainbow P.S., Biomonitoring of trace aquatic contaminants, Elsevier Applied Science (1992).

[37] Richmond R.H., Coral reefs: Present problems and future concerns resulting from anthropogenic disturbance, Amer. Zool. 33 (1993) 524-536.

[38] Scbens K.P., Biodiversity of coral reefs: What are we losing and why? Amer. Zool. 34 (1994) 115-133.

[39] Sharp V.A., Heat shock protein (hsp 70) expression in the tropical reef coral Goniopora djiboutiensis, J. Therm. Biol. 21 (1996) 236-253.

[40] Sharp V.A., Weeks J.M., Williams T.M., Setiapermana D., Land-derived contaminant influx to Jakarta Bay, Indonesia, Vol. 3: Community structurc and tissuc level contamination of reef-building corals, British Geological Survey: Overseas Geology Series: Technical Report WC/97/55, Keyworth, Nottingham, UK, 1997.

[41] Sheppard C.R.C., Coral fauna of Diego Gracia lagoon following harbour construction, Mar. Poll. Bull. 11 (1980) $227-230$. 
[42] Suharsono, Ecological and physiological implication of coral bleaching at Pari Island, Thousand Islands, Indonesia, PhD Thesis, Univ. Newcastle upon Tyne, 1990, 279 p.

[43] Suharsono Kiswara W., Kematian alami karang di Laut Jawa (Natural death of corals in the Java Sea), Oceania 9 (1984) $31-40$.

[44] Sukarno, Penelitian pendahuluan tentang kepadatan karangbatu di terumbu karang Pulau Air, Pulau-Pulau Seribu, (Preliminary study on the diversity and some environmental factors of stony corals on the reefs of Pulau Air, Thousand Islands), Oceanologi Indon. 8 (1977) 33-43.

[45] Svendsen C., Wecks J.M., The use of a lysosomal assay for the rapid assessment of cellular stress from copper to the freshwater snail Viviparus contectus (Millet), Mar. Poll. Bull. 31 (1995) 139-142.

[46] Thayib S.S., Martoyudo W., Suhadi F., Berapa macam bakteri penyebab penyakit perut manusia pada kerang Andara dan Crossostera (Some enteropathogenic bacteria in clams (Andara) and oysters (Crassostera) Oceanologi Indon. 7 (1977) 49-55.

[47] Tomascik T. Sander F., Effects of eutrophication on reef-building corals, II Structure of scleractinian coral communities on fringing reefs, Barbados, West Indies, Mar. Biol. 94 (1987) $53-75$.

[48] Tomascik T., Suharsono Anmarie J.M., Case histories: A perspective of the natural and anthropogenic impacts in the Indonesian Archipelago with a focus on the Kepulauan Seribu, Java Sea, in: Ginsburg R.N., Glynn P.W. (Eds.), Proc. Coll. Global Aspects of Coral Reefs, Health Hazards and History, Univ. Miami, 1993, 304-310.

[49] Umbgrove J.H.F., De koraalriffen in de Baai van Balavia, Dienst Mijnb., Ned. Indie, Wetensch. Meded. 7 (1928) 1-69.

[50] Umbgrove J.H.F., De koraalriffen der Duizend Eilanden, Dienst Mijnb., Ned. Indie, Wetensch. Meded. 12 (1929) 1-47.
[51] Umbgrove 5.H.F., Madreporaria from the Bay of Batavia. Zool. Meded. Leiden 22 (1939) 1-64.

[52] Umbgrove J.H.F., Coral Reef in the East Indies, Bull. Geol. Soc. Amer. 58 (1947) 729-778.

[53] US Navy Hydrographic Office, Currents in the South China, Java and Sulu Seas, Hydrographic Office Publication 236 , Washington, 1945.

[54] Verstappen H.T., Djakarta Bay, a geomorphological study on shoreline development, Thesis Univ. Utrecht, 1953, $101 \mathrm{p}$.

[55] Verwey J., Coral Reef Studies II. The depth of coral reefs in relation to their oxygen consumption and the penetration of light in the water, Treubia 13 (1931)169-198.

[56] Walker D.I., Ormond R.F.G., Coral death from sewage and phosphate pollution at Aqaba, Red Sea, Mar. Poll. Bull. 13 (1982) 21-25.

[57] Warwick R.M., Clarke K.R. Suharsono, A statistical analysis of coral community responses to the 1982-83 El Nino in the Thousand Islands, Indonesia, Coral Reefs 8 (1990) 171179.

[58] Weeks J.M., Sharp V.A., Williams T.M., Land-derived contaminant influx to Jakarta Bay, Indonesia, Vol. 2: Contaminantinduced lysosomal membrane damage in blood cells of green mussel Perna viridis (Mytilidae): a field transplant study, British Geological Survey: Overseas Geology Series: Technical Report WC/97/64, Keyworth, Nottingham, UK, 1997.

[59] Williams T.M., Rees J.G, Ferguson A., Herd R.A, Kairu K.K., Yobe A.C., Metals, petroleum hydrocarbons and organochlorines in inshore sediments and waters of Mombasa, Kenya, Mar. Poll. Bull. 34 (1997a) 570-577.

[60] Williams T.M., Rees J., Setiapermana D., Land-derived contaminant influx to Jakarta Bay, Indonesia, Vol. 1: Geochemistry of marine water and sediment, British Geological Survey: Overseas Geology Series: Tcchnical Report WC/97/19, Keyworth, Nottingham, UK, $1997 \mathrm{~b}$. 